\title{
Phylogeography of the reef-building polychaetes of the genus Phragmatopoma in the western Atlantic Region
}

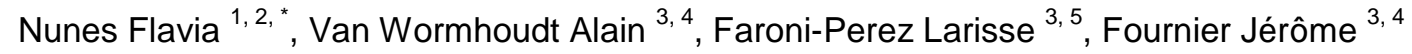

${ }^{1}$ Laboratoire des Sciences de l'Environnement Marin; LEMAR UMR 6539 CNRS/UBO/IRD/Ifremer; Université de Brest (UBO); Université Européenne de Bretagne (UEB); Institut Universitaire Européen de la Mer (IUEM); Plouzané ,France

${ }^{2}$ Ifremer Centre Bretagne; DYNECO; Laboratoire d'Ecologie Benthique Côtière (LEBCO); Plouzané, France

${ }^{3}$ Muséum National d'Histoire Naturelle; Station de Biologie Marine; Concarneau ,France

${ }^{4}$ CNRS; UMR 7208 BOREA; Muséum National d'Histoire Naturelle; Paris, France

${ }^{5}$ PPGECO; Department of Zoology and Ecology; Federal University of Santa Catarina; Florianópolis, Brazil

*Corresponding author : Flavia Nunes, email address : $\underline{\text { flavia.nunes@ifremer.fr }}$

\begin{abstract}
:
Aim

To verify the synonymy of the reef-building polychaete Phragmatopoma caudata (described for the Caribbean) and Phragmatopoma lapidosa (described for Brazil) using molecular data. To evaluate the patterns of genetic diversity and connectivity among populations from Florida to South Brazil.

Location

Intertidal zone in the western Atlantic biogeographical Region: Brazil, eastern Caribbean and Florida (USA).

\section{Methods}

DNA sequence data from one mitochondrial (cox-1) and one nuclear ribosomal (ITS-1) loci were obtained from 11 populations of $P$. caudata spanning the coasts of Brazil, eastern Caribbean and Florida. Phylogenetic relationships among populations of $P$. caudata and other members of the genus were inferred by Bayesian methods. Population differentiation was evaluated by Bayesian analysis of population structure (baps), AMOVA and pairwise $\varphi s t$. Demographic history was inferred by Bayesian skyline plots.
\end{abstract}


Results

Phylogenetic inference supported the interpretation of a single species of Phragmatopoma spanning the Brazilian and Caribbean Provinces of the western Atlantic Region. Little population structure was observed across the species distribution, with the exception of the Florida population. The baps analysis supported a 2-population model, with population differentiation being strong and significant between Florida and all other Atlantic populations for cox-1, and significant between Florida and most populations for ITS-1. Differences in genetic diversity were not significant between Caribbean and Brazilian populations, although several populations in Brazil had low values for diversity indices. Bayesian skyline plots indicate population expansion starting at c. $200 \mathrm{ka}$.

Main conclusions

Phragmatopoma caudata is able to maintain genetic connectivity across most of its geographical range, with population differentiation being observed only between Florida and all other localities, possibly due to ecological speciation in the transition zone between tropical and subtropical environments. Longdistance connectivity across much of the species range is likely the result of long-lived larvae that are tolerant to a wide range of environmental conditions. 


\section{Introduction}

Many benthic marine invertebrates have patchy distributions as a result of the interaction among abiotic and biotic variables that limit dispersal, settlement and survival. Discontinuous distributions can affect population connectivity even in species with a long planktonic larval stage, having consequences for gene flow, genetic diversity and speciation. Thus, benthic marine invertebrates provide interesting models for addressing questions related to how species distributions reflect the interplay among dispersal dynamics, environmental conditions, biotic interactions or historical isolation (Avise, 1992; Palumbi, 1994). The tropical Atlantic fauna are affected by five major biogeographical barriers: the Mid-Atlantic Barrier, the Terminal Tethyan Event, the Amazon-Orinoco Barrier, the Isthmus of Panama and the Benguela Barrier (Floeter et al., 2008). But while these barriers are effective for numerous species, exceptions exist for each one, providing opportunities for understanding the variables that contribute to species distributions, their delimitations and connectivity among their populations.

Some marine polychaetes from the family Sabellariidae Johnston, 1865 are gregarious and are important reef-building organisms in coastal environments (Goldberg, 2013). These ecosystem engineers create complex habitats supporting high levels of biodiversity, and provide ecosystem services such as coastal protection (Dubois et al., 2002; Noernberg et al., 2010; Ataide et al., 2014). While most sabellariids are solitary, the species that are reef-building typically construct biogenic structures in intertidal or shallow subtidal environments (Faroni-Perez et al., 2016). Reefs of Phragmatopoma caudata Krøyer in Mörch, 1863 are broadly distributed along the intertidal zone in the western Atlantic coastline, from Florida (USA) $\left(34^{\circ} \mathrm{N}\right)$ to Santa Catarina (Brazil) $\left(27^{\circ} \mathrm{S}\right)$, including many localities in the Caribbean (Kirtley, 1994). Although P. caudata reefs are known to exist at various locations along the Brazilian coast (Pagliosa et al., 2014), records in new localities continue to be reported. For instance, new reefs formed in Fortaleza (north Brazil) following the construction of a harbour (Fournier \& Panizza pers. obs.). Currently, the northernmost known occurrence of the species in Brazil is in the state of Piauí (Santos et al., 2012). Beyond the Amazon and Orinoco Rivers, the species has also been recorded in Venezuela (Liñero-Arana, 2013). Discontinuities in the range cannot at present be stated with certainty, as field observations in this geographical region are far from exhaustive, and areas with confirmed absences have yet to be described. The abundance and 
78 distribution of sabellariid reefs depend on the availability of a hard substrate, suspended sediments, and

79 appropriate levels of turbulence (Main \& Nelson, 1988). Phragmatopoma caudata (as P. lapidosa Kinberg,

80 1866) reproduces by external fertilization of gametes that are produced year-round (Eckelbarger, 1976).

81 Spawning and recruitment are highest in the summer months, from June to August in Florida, USA

82 (McCarthy et al., 2003) and February to April in São Paulo State, Brazil (Faroni-Perez, 2014). Fecundity is

83 high, as the average female can spawn 1500-2000 oocytes (McCarthy et al., 2003), indicating a high

84 potential for dispersal. During development, planktonic larvae drift in the water column from two to four

85 weeks (Mauro, 1975; Eckelbarger, 1976). Larvae tolerate a wide temperature range $\left(15.5^{\circ} \mathrm{C}-29.5^{\circ} \mathrm{C}\right)$, but

86 beyond these extremes, development and survival are compromised (Eckelbarger, 1976). While tolerance to

87 salinity has not yet been quantified for larvae, adults can tolerate brackish waters of up to $30-40 \%$ seawater

88 (Mauro, 1977). When metatrochophore larvae are competent for metamorphosis, they settle onto hard

89 substrate, usually a conspecific pre-existing reef, induced by chemical cues (Pawlik, 1988) and mediated by

90 the larval sensory organs, such as the dorsal hump and palps (Faroni-Perez et al., 2016). Finally, P. caudata

91 has an estimated lifespan of one to two years (McCarthy et al., 2003).

92 Systematics of the genus have been recently revised (Drake et al., 2007; Capa et al., 2012).

93 Notwithstanding, the brief original descriptions for P. caudata and P. lapidosa and the disappearance of the

94 type material led to uncertain taxonomic status. Hartman (1944) questioned whether the two species were

95 distinct, and upon revision of Sabellariidae, Kirtley (1994) synonymized P. lapidosa with P. caudata. More

96 recently, molecular phylogenetics supported a single Caribbean species, with distinct populations in Florida

97 and West Indies (Drake et al., 2007). However, patterns of oogenesis in individuals from Florida differed

98 from those in Brazil, reopening the debate on plasticity or speciation (Faroni-Perez \& Zara, 2014).

99 Moreover, intraspecific variability in the composition of the cement used for reef construction was found

100 along the Brazilian coast, suggesting potential differences among populations (Fournier et al., 2010).

101 Currently, no molecular study has taken Brazilian populations into consideration, and the question remains 102 whether a single species is distributed from Florida to South Brazil. 
The aims of this study are i) to examine if a single Phragmatopoma species occurs in the Western

104 Atlantic Region, ii) to assess the genetic connectivity among populations of $P$. caudata in the Caribbean and 105 Brazilian biogeographical provinces and iii) to assess the effectiveness of putative biogeographical barriers 106 on the connectivity of P. caudata.

108 Materials and Methods

109 Study sites and sampling method

Phragmatopoma caudata was collected from seven sites spanning its distribution along the coast of

111 Brazil: Fortaleza (FOR), Tamandaré (TAM), Peracanga (PER), Ubatuba (UBA), Ilha Porchat (POR),

112 Itanhaém (ITA) and Ilha do Mel (MEL). In addition, four sites in the Caribbean were analysed: three

113 previously sampled sites in Florida, USA (FLO), Puerto Rico (PRI) and Virgin Islands (VIL), and one new

114 site in Guadeloupe Island (GUA) (Figure 1, Appendix S1). Specimens were collected at low tide by

115 breaking off small blocks of reef and removing 1-3 worms from each block. At each locality, several reef

116 blocks were collected, separated by tens of meters, to ensure good representation of genetic diversity at each 117 site. Individual specimens were fixed in $70 \%$ ethanol and stored at $-20^{\circ} \mathrm{C}$.

DNA extraction and sequencing

DNA was extracted using the CTAB method (Denis et al., 2009). Two loci were used in order to make comparisons with previously studied Caribbean populations (Drake et al., 2007): the mitochondrial

122 cytochrome c oxydase subunit I (cox-1) and the first internal transcribed spacer region (ITS-1) of the 123 ribosomal DNA. New primers were designed for cox-1: PHRALCO: 5' -

124 TTTATATTTTGGAATTTGGTCAGG -3 '; PHRAHCO: 5' - TAAAGAACTGGGTCTCCACC-3'. 125 Published primers were used for ITS-1 (ITS1-fw: 5'-CACACCGCCCGTCGCTACTA-3', ITS3r: 5'126 TTCGACSCACGAGCCRAGTGATC-3') (Denis et al., 2009). Amplification was performed with the 127 Ready-to-Go PCR kit (GE Healthcare, Little Chalfont, UK) using $0.1 \mu$ g of DNA. Thermal cycler conditions 128 included an initial denaturation step at $96^{\circ} \mathrm{C}$ for 2 min, 40 cycles at $96^{\circ} \mathrm{C}$ for $30 \mathrm{~s}, 52^{\circ} \mathrm{C}$ for 30 s and $72^{\circ} \mathrm{C}$ for $1291 \mathrm{~min}$, with a final extension at $72^{\circ} \mathrm{C}$ for $5 \mathrm{~min}$. After electrophoresis, PCR products were extracted from the 
130 agarose gel and purified using the Wizard SV Gel System (Promega, Fitchburgh, WI, USA). Cloning was 131 carried out for a subset of the ITS- 1 amplifications (23 individuals), to confirm the phase of heterozygous 132 alleles. PCR products were ligated into the pGEMT Easy vector (Promega, Fitchburgh, WI, USA) and 133 transformed into JM 109 competent cells (Promega, Fitchburgh, WI, USA). Five colonies were sequenced 134 for each individual. Sequencing reactions used the BigDyev.3.1 chemistry (Applied Biosystems, Waltham, 135 MA, USA) and was analysed on an ABI 3130 automated sequencer.

Molecular data analysis

DNA sequence chromatograms were inspected for errors and edited with SEQUENCHER 4.5 (Gene

139 Codes Corp, Ann Arbor, MI, USA). Published sequences of Phragmatopoma caudata [Genbank accession 140 numbers: DQ172733- DQ172763, DQ172801-DQ172810], Phragmatopoma californica (Fewkes, 1899) 141 [DQ172682-DQ172732, DQ172768-DQ172800], Phragmatopoma moerchi Kinberg, 1866 [DQ172764] and 142 Phragmatopoma virgini Kinberg, 1866 [DQ172813-DQ172822, DQ172811-DQ172812] were added to the 143 dataset, and sequences of Idanthyrsus cretus Chamberlain 1919 [DQ172680-DQ172681, DQ172765-

144 DQ172767] were used for the outgroup (Drake et al., 2007). Sequence alignment was performed using 145 ClustALX in MEGA 6.0.6 using default parameters (Tamura et al., 2013). For ITS- 1 sequences containing 146 double peaks in both sequencing directions, cloned sequences and the sequences of homozygous individuals 147 were used for haplotype reconstruction using PHASE implemented in DNASP 5 (Librado \& Rozas, 2009). 148 For phylogenetic analysis, all redundant sequences were removed, such that phylogenetic inference was 149 made with unique sequences. A gene tree was constructed for each locus in BEAST 1.8.2 and species tree 150 ancestral reconstruction was estimated combining both cox- 1 and ITS- 1 with the *BEAST algorithm (Heled $151 \&$ Drummond, 2010). The best-fit model of nucleotide substitution was determined by hierarchical 152 likelihood ratio test in MRMODELTEST 2.2 (https://github.com/nylander/MrModeltest2). The GTR $+\Gamma+\mathrm{I}$ 153 substitution model was used for $c o x-1$ and the $\mathrm{HKY}+\Gamma$ model was used for $I T S-1$. A strict molecular clock 154 was employed with a fixed substitution rate of $2.1 \%$ per Myr for cox- 1 and $0.25 \%$ per Myr for ITS- 1 . In the 155 species tree, clock rates were estimated relative to $c o x$ - 1 . Substitution rates vary across species and genes, 
156 and depend on the accurate timing of vicariant events or fossil occurrences, which can incur considerable

157 uncertainties. However, averaging the rates obtained for the same gene over several closely related taxa can 158 improve the confidence of molecular clock estimates. The substitution rate selected for cox- 1 corresponds to 159 the average rate across 27 transisthmian crustacean species pairs (Lessios, 2008). In addition, a rate of 2.1\% 160 per Myr (based on crustaceans) has also been employed in previous work on Phragmatopoma spp. (Drake et 161 al., 2007). Fewer estimates of substitution rates are available for the invertebrate ITS- 1 locus. The rate of $1620.25 \%$ per Myr used for Phragmatopoma was estimated for a marine gastropod (Coleman \& Vacquier, 163 2002).

164 For phylogenetic analysis, the Markov chain Monte Carlo (MCMC) ran for 30 million generations 165 with sampling at every 1000 steps. The results of three independent runs were verified for conversion using 166 TRACER 1.5 and combined after discarding a burn-in of $20 \%$ using LOGCOMBINER 1.8.2. Target trees used 167 the maximum clade credibility criterion in TREEANNOTATOR 1.8.2. Nodes with a posterior probably inferior 168 to 0.90 were collapsed. Estimates of genetic distance between species pairs were calculated using the 169 Kimura 2-parameter model in MEGA 6. For cox-1, positions containing missing data were eliminated, while 170 for ITS- 1 positions containing gaps between sequence pairs were removed. Divergence time estimates based 171 on genetic distances used the same substitution rates listed above. Relationships among haplotypes (including redundant sequences) were inferred with a haplotype 173 network based on maximum parsimony, constructed with TCS 1.21(Clement et al., 2000). Haplotype 174 frequencies, the number of unique haplotypes $(\mathrm{H})$, segregating sites (s), haplotype diversity $(\mathrm{h})$ and 175 nucleotide diversity $(\pi)$ were calculated for each sampling site using ARLEQUIN 3.1 (Excoffier et al., 2005). 176 Deviations from neutrality were assessed with Tajima's D and Fu's Fs statistics in ARLEQUIN. Population 177 demographic history was inferred by Bayesian skyline plots implemented in BEAST (Drummond et al., 178 2005). The population size function of the Bayesian skyline plots were fitted using a piecewise constant 179 function, with 10 groups. In order to obtain an effective sampling size of at least 200, the MCMC chain ran 180 for 50 million generations and was sampled every 100 for cox- 1 , and for ITS- 1 , the MCMC ran for 40 181 million generations sampled every 1000. 
Population structure was explored for both loci using Bayesian analysis of population genetic

183 structure (BAPS; Corander et al., 2008), a clustering algorithm which uses a Bayesian predictive model to

184 estimate the number of genetically diverged groups based on molecular data. A population mixture analysis

185 was run using the "clustering with linked loci" option. Single-locus sequence data are expected to be

186 genetically linked because of their close proximity along the chromosome. This option therefore takes into

187 consideration the non-independence of linked loci. The clustering of groups with the lowest log likelihood

188 was selected.

Population differentiation was assessed by analysis of molecular variance (AMOVA) and pairwise

$190 \varphi$ st in ARLEQUIN (Excoffier et al., 2005). The significance level of pairwise tests was adjusted by a

191 Bonferroni correction. For the three-level hierarchical AMOVAs, the results of the BAPS analysis were used 192 to select biogeographical divisions.

\section{Results}

195 Properties of the DNA sequences

After sequence quality screening and trimming, a total of 146 sequences of $497 \mathrm{bp}$ length were

197 obtained for cox- 1 and 99 sequences of 403 bp length were obtained for ITS- 1 for P. caudata. Sequences

198 were deposited in Genbank (accession numbers: KT182639 - KT182784 for cox-1 and KT182785 -

199 KT182883 for ITS-1). For the cox-1 locus, population genetic analyses were calculated (1) considering all

200 three codon positions, and (2) with the third codon position excluded. Because of high polymorphism in the

201 third codon position, $74 \%$ of sequences were unique, leading to a haplotype network characterized by

202 numerous loops, indicating homoplasy. Moreover, the AMOVA and population differentiation results were

203 similar whether the third codon position was kept or excluded from the analysis. Therefore, results shown

204 for haplotype network, allele frequencies, genetic diversity, AMOVA, pairwise $\varphi$ st and BAPS consider only 205 the first and second codon positions, while all three codon positions were kept for phylogenetic analysis and 206 Bayesian skyline plots.

Previous work has shown that multiple alleles (>2) can be observed for ITS-1(Drake et al., 2007).

208 Among all sequences, multiple peaks were found in 23 nucleotide sites. More than one allele was observed 
209 for nearly all individuals (identified either by cloning or by haplotype reconstruction), but only eight

210 individuals had more than two sites with multiple peaks. Because the present study combined published data

211 (from Drake et al., 2007) with new data, only one allele per individual was kept in the analysis as was done

212 previously. A random number generator was used to select the haplotype kept in the analysis, to ensure that

213 allele selection did not bias the dataset towards lower diversity by selecting the most common allele, with

214 the caveat that this approach does not discriminate paralogous from orthologous alleles. Few mutational

215 differences were observed among intra-individual alleles (maximally nine mutations); therefore inadvertent

216 selection of paralogous alleles likely had only a small effect on estimates of genetic diversity or

217 differentiation.

Phylogenetic analysis

All three species of Phragmatopoma (P. caudata, P. californica and P. virgini) were monophyletic for cox-1, ITS-1 and the species tree combining both loci (Figure 2). However, all phylogenetic reconstructions found the relationship between the three species to be unresolved. Low support was found for $P$. caudata being sister taxon to $P$. californica in the species trees ( $\mathrm{pp}=0.40$; Figure 2a), for $P$.

224 californica being sister to $P$. virgini in the ITS- 1 tree ( $\mathrm{pp}=0.21$; node collapsed; Figure $2 \mathrm{~b}$ ), and for $P$. 225 caudata being sister to $P$. virgini in the $\operatorname{cox}-1$ tree ( $\mathrm{pp}=0.86$; node collapsed; Figure $2 \mathrm{c}$ ). Sequences of 226 individuals of $P$. caudata from Brazil belonged to the same clade as those from the Caribbean (Figure $2 \mathrm{~b}, \mathrm{c}$ ) 227 and identical sequences were observed among some individuals from Brazil and the Caribbean. However, $P$. 228 caudata from Florida formed a reciprocally monophyletic clade with $P$. caudata from the rest of the 229 Caribbean+Brazil, having high support in the analyses using cox- 1 and the combined loci ( $\mathrm{pp}=1.00$ for both 230 trees; Figure 2 a,c).

Pairwise genetic distances and divergence time estimates are shown in Table 1. Based on cox-1, $P$. 233 estimated with ITS-1 indicate an older split between $P$. caudata and P. californica, at $28.2 \pm 5.4$ Ma, and of $234 \quad 33.1 \pm 5.9$ Ma between $P$. caudata and $P$. virgini. $P$. caudata from Florida diverged from the remaining $P$. 
Haplotype networks and haplotype frequencies

Haplotype frequencies for cox- 1 and ITS- 1 are shown in Figures $1 \mathrm{~b}-\mathrm{c}$, and maximum

parsimony haplotype networks are shown in Figure 3. Among the 17 haplotypes sequenced for cox-1, two

were abundant among the sampled populations ( $\mathrm{C} 5$ and $\mathrm{C} 1$ ), three were present in more than one population

at low frequencies (C6, C8 and C11), with the remainder being observed in only one individual (singletons)

and being restricted to one population (private haplotypes) (Figure 3a). Haplotype C5 was abundant in most populations, ranging in frequency from $69-100 \%$, except in Florida, where it was absent. Haplotype C1

was abundant only in Florida (75\%) and was found in three other Brazilian populations at low frequencies

(Figure 1b). Overall, nearly all populations had similar haplotype frequencies for $c o x-1$ across the range of

P. caudata, including populations in Caribbean and Brazil, with the exception of the Florida population.

Among the 22 haplotypes sequenced for ITS-1, six were present in more than one population

248 (in order of abundance: T7, T8, T4, T1, T3 and T13), and the remainder were private haplotypes (Figure 3b).

249 The most common haplotype (T7) was abundant in all Brazilian populations (40-80\%) and one Caribbean

250 population (GUA, 40\%). Haplotype T7 was also present in Puerto Rico and the Virgin Islands, but at lower

251 frequencies (8-9\%), and was absent in Florida (Figure 1c). Haplotypes T1 and T3 were found only in the

252 Caribbean Province (including Florida). In sum, haplotype frequencies for ITS- 1 were similar among

253 Brazilian populations, with greater variability being observed among the Caribbean populations. The Florida

254 population had the most divergent pattern, with a high abundance of haplotype T1 (42\%), which was absent

255 from most other populations, except for the Virgin Islands (18\%).

\section{Genetic Diversity}

Genetic diversity indices were usually greater in the Caribbean populations (FLO, PRI, VIL, GUA) relative to the Brazilian populations (FOR, TAM, PER, UBA, POR, ITA, MEL). For example, gene diversity among Caribbean populations was greater than among Brazilian populations for both cox-1 ( $0.426 \pm 0.121$ compared to $0.243 \pm 0.195)$ and $I T S-1(0.854 \pm 0.06$ compared to $0.692 \pm 0.178)$, although these 
263 nucleotide diversity was greater in the Caribbean rather than Brazilian populations for both cox-1 and ITS-1,

264 but again, the difference was not significant ( $\mathrm{p}=0.166$ and $\mathrm{p}=0.07$ for $c o x-1$ and ITS -1 respectively)

265 (Appendix S2). Within both regions, genetic diversity was variable across populations, but in Brazil,

266 variability was greater, with some populations having values similar to the Caribbean, while others had 267 much lower diversity.

268 Deviations from neutral expectation were also observed. Tajima's D was negative for five out of 11 269 populations in cox-1 and Fu's Fs indicated significant deviation from neutrality for seven populations for 270 cox-1 and three populations for ITS-1 (Appendix S2). These large negative values for Fu's Fs suggest recent 271 population expansion in the Caribbean, and in several Brazilian populations. Bayesian skyline plots for both 272 cox-1 and ITS-1 also support an interpretation of recent population expansion, dating to $\sim 200$ ka (Figure 4).

273 The age estimate for population expansion of $P$. caudata is concordant for both loci, even though

274 independent molecular clocks were used. Population structure has been shown to have a confounding effect 275 on demographic history (Heller et al., 2013). Because strong differentiation was observed with respect to the 276 Florida population, Bayesian skyline plots were also estimated after excluding sequences from Florida 277 (Figure 4b, d). Regardless of whether individuals from Florida were excluded or kept in the analysis, a 278 signature of population expansion was observed, all dating to $\sim 200 \mathrm{ka}$.

\section{Population differentiation}

BAPS found two genetically distinct groups for cox-1, among the sampled P. caudata localities $282\left(\log _{\mathrm{ML}}=-1905.8\right)$. All individuals assigned to one group were sampled from Florida, while the remaining 283 individuals, sampled across all other populations in the Caribbean and Brazil, were assigned to the second 284 group (Appendix S3). In order to examine whether further population structure occurred within the second 285 group, an analysis was conducted excluding individuals from Florida. However, no further genetically 286 distinct groups were identified, as all individuals from this reduced dataset were still all assigned to the same 287 group ( $\left.\log _{\mathrm{ML}}=-1607.3\right)$. For ITS-1, BAPS found four genetically distinct groups $\left(\log _{\mathrm{ML}}=-352.4\right)$; but, only one individual was assigned to two of the four groups. The log likelihood for two groups was similar to four groups $\left(\log _{\mathrm{ML}}=-393.5\right)$, but there was no clear geographic pattern in the assignment of individuals to either 
290 group. For example, one group contained individuals from Florida, the Caribbean (in PRI and GUA) and

291 Brazil (TAM, PER and POR) (Appendix S3). The BAPS analysis therefore did not indicate any strong

292 geographical trend in population differentiation for ITS-1.

The hierarchical population structure design in the AMOVA considered two groups (group 1: FLO;

294 group 2: all other populations). This scenario was selected based on the results of the BAPS analysis (for 295 cox-1), and patterns in haplotype frequencies and haplotype networks for both loci. Differentiation among 296 populations $\left(\mathrm{F}_{\mathrm{ST}}\right)$ was significant for both $\operatorname{cox}-1\left(\mathrm{~F}_{\mathrm{ST}}=0.721, \mathrm{p}<0.00001\right)$ and $\operatorname{ITS}-1\left(\mathrm{~F}_{\mathrm{ST}}=0.21338\right.$, $297 \mathrm{p}<0.00001)$. Differentiation among groups was also significant for ITS-1 $\left(\mathrm{F}_{\mathrm{CT}}=0.196, \mathrm{p}=0.00098\right)$. Although 298 the $\mathrm{F}_{\mathrm{CT}}$ value was high for $\operatorname{cox}-1\left(\mathrm{~F}_{\mathrm{CT}}=0.721\right)$, it was not significant ( $\left.\mathrm{p}=0.088\right)$ (Table 2). These results 299 indicate that there is some significant population structure among $P$. caudata populations, and that much of 300 this structure is due to the Florida population.

Values of pairwise $\varphi$ st for cox- 1 clearly indicate strong differentiation of the Florida population with respect to all other Caribbean and Brazilian populations ( $\varphi$ st ranges from 0.606-0.784) (Table 3). For all other pairwise comparisons, $\varphi$ st was small and not significant, suggesting that connectivity is maintained

304 among populations along the coast of Brazil and among the eastern Caribbean Islands. For ITS-1, nearly all 305 pairwise $\varphi$ st comparisons were non-significant after Bonferroni correction (except PER compared to FLO 306 and PRI), indicating that for this locus, although some population structure can be detected, connectivity 307 appears to be maintained among most populations.

\section{Discussion}

Phylogenetic analysis based on cox- 1 and ITS- 1 confirms the monophyly of three species of

311 Phragmatopoma (P. caudata, P. californica and P. virgini). In addition, our analyses which included one 312 published sequence of $P$. moerchi, also indicate that this may be a separate species, as suggested by Drake $e t$ 313 al. (2007). In contrast to previous work, however, the results presented here do not show conclusive 314 phylogenetic relationships among $P$. caudata, $P$. californica and P. virgini, as trichotomies were observed in 315 the cox-1, ITS- 1 and in the species trees. Sequencing of additional loci or sampling of additional species in 
316 the genus (such as $P$. attenuata from the Pacific, or more individuals of $P$. moerchi) may help to clarify

317 phylogenetic relationships within the genus.

Phylogenetic analysis also indicates the existence of a single species - Phragmatopoma caudata-

319 from the eastern Caribbean to southern Brazil. These are the first molecular data to support a single species

320 spanning this broad geographical range, confirming Kirtley’s (1994) synonymization of P. lapidosa

321 (originally described from Brazil) and P. caudata (originally described from the Caribbean). However, two

322 genetically differentiated lineages were also identified - one that spans the Brazilian coast and part of the

323 Caribbean and another that is restricted to Florida. Genetic differentiation with respect to Florida is

324 congruent with contrasting patterns of oogenesis observed between P. caudata from Brazil and Florida

325 (Faroni-Perez \& Zara, 2014). For instance, the ovaries in P. caudata from Brazil were composed of oogonia

326 and oocytes attached to blood vessels during early development, whereas in Florida, oocytes were associated

327 with blood vessels until the end of vitellogenesis. Several additional features of oogenesis differed between

328 individuals from either locations, including the type of oogenesis (intra- versus extra-ovarian), the nature of

329 oocyte development (auto versus heterosynthetic), and the locations of the oocyte mitochondria cloud, Golgi

330 complexes and ovary capsules (Faroni-Perez \& Zara, 2014). These findings show various distinctive aspects

331 of gametogenesis between Florida and Brazil. Characterization of reproductive traits in individuals from

332 Puerto Rico and Virgin Islands (geographically close to Florida, but genetically more similar to Brazil)

333 could help elucidate whether reproductive differences are associated with the genetic differentiation

334 observed here, and whether species-level distinction is warranted with respect to P. caudata from Florida.

Recent reassessments in Atlantic biogeography find the marine fauna within the Greater Caribbean

336 to be relatively homogeneous, with the Caribbean Province being comprised of all the northern Western

337 Atlantic tropics, including the southern tip of Florida and the West Indian islands (Floeter et al., 2008;

338 Briggs \& Bowen, 2012). Phragmatopoma caudata, however, differs from this general trend, and shows a

339 split between south Florida and nearby West Indian islands. The isolation of the Florida population may

340 have three possible explanations. Firstly, the fast flowing currents in the Florida Straits may hinder larval

341 dispersal between Florida and the West Indies (Briggs, 1995), as has been suggested for Symbiodinium

342 harboured by the octocoral Gorgonia ventalina (Andras et al., 2011). A second possibility is long-term 
343 divergence between Caribbean and Brazilian lineages, followed by recent dispersal from Brazil into the

344 West Indies, as suggested for the rock hind Epinephelus adscensionis (Carlin et al., 2003). Finally, the

345 Florida population may be a case of incipient or recent speciation. Phylogenetic analysis based on cox- 1 and 346 the species tree based on both loci show high support for a Florida clade (Figure 2), indicating a possible 347 cryptic species. Because phylogenetic analysis based on ITS-1 alone does not identify a Florida clade, these 348 results require verification from additional molecular markers and/or morphological comparisons between 349 specimens from Florida and the rest of the range of $P$. caudata. However, differences in gonad development 350 between $P$. caudata from Brazil and Florida support the interpretation of a cryptic species (Faroni-Perez \& 351 Zara, 2014). Florida is a transition zone between the tropics and subtropics, where ecological speciation 352 could take place as different genotypes become adapted to contrasting environmental conditions in different 353 habitat types. The wrasse Halichoeres bivittatus provides a compelling example of ecological speciation in 354 the marine environment (Rocha et al., 2005). In this species, genetic connectivity is maintained across $355>2400 \mathrm{~km}$, from Belize to the Lesser Antilles, but strong differentiation is observed between tropical 356 Bahamas and subtropical Florida, separated by only $300 \mathrm{~km}$. In the Florida Keys, where tropical and 357 subtropical habitats exist in close proximity, subtropical genotypes of this species were found in cooler 358 inshore channels while tropical genotypes were found in warmer offshore reefs (Rocha et al., 2005).

359 Ecological speciation in P. caudata is an intriguing hypothesis for the genetic break observed between the 360 West Indies and Florida, and future work examining contrasting habitats along the coast of Florida and 361 adjacent areas may help to clarify the mechanisms that have led to genetic isolation in this location. While genetic differentiation between Florida and the eastern Caribbean has previously been 363 documented in P. caudata (Drake et al., 2007), our work reveals continued genetic connectivity across the 364 Amazon-Orinoco Barrier, among populations separated by as much as $9000 \mathrm{~km}$. The Amazon plume is an 365 important barrier to dispersal for a variety of marine species such as corals (Nunes et al., 2009, 2011), 366 crustaceans (Terossi \& Mantelatto, 2012), echinoderms (Lessios et al., 2003), and reef fish (Mendonça et al., 367 2013). However, it is considered a "soft barrier" or "filter" because of the large number of shared fish 368 species on either side of the barrier (Floeter et al., 2008). Indeed, connectivity between the Caribbean and 369 Brazilian Provinces has been observed in several marine species, such as ascidians (Nóbrega et al., 2004), 
370 sea urchins (Zigler \& Lessios, 2004), sponges (Lazoski et al., 2001) and fish (Floeter et al., 2008). Similarly,

371 the Amazon-Orinoco Barrier does not appear to be an effective barrier for dispersal for P. caudata, even

372 though occurrences on either side of the Amazon and Orinoco Rivers (Parnaiba, Brazil and Puerto Viejo,

373 Venezuela) indicate that populations may be separated by up to $2700 \mathrm{~km}$. Connectivity among populations

374 of P. caudata in Brazil and the West Indies may be maintained by the North Brazil and Guiana Currents,

375 both flowing northward from the north-eastern point of Brazil towards the Amazon and onwards to the

376 Caribbean (Figure 1a). In addition, the Amazon River discharge varies seasonally, and is weakened from

377 January to April (Molleri et al., 2010), potentially allowing larval permeability from North Brazil to the

378 eastern Caribbean Islands. Larvae of $P$. caudata develop over two to four weeks (Eckelbarger, 1976), likely

379 contributing to the ability to disperse broadly and to maintain connectivity across great distances. Moreover,

380 larvae of $P$. caudata can develop normally between $15.5-29.5^{\circ} \mathrm{C}$, a relatively wide temperature range

381 (Eckelbarger, 1976). Tolerance to salinity in larvae of $P$. caudata is currently unknown, but could be an

382 additional parameter favouring long-distance dispersal. Further experiments are needed to determine

383 tolerance to environmental variability in larvae, but such traits could explain dispersal across the Amazon-

384 Orinoco Barrier.

385 At the intra-specific level, cox-1 was characterized by a high number of private alleles (haplotypes 386 restricted to one population), and singletons (haplotypes observed in only one individual) in all populations 387 of $P$. caudata. Interestingly, all singleton mutations were synonymous (i.e. did not alter the amino acid 388 sequence of a protein). A large number of singletons could be due to a high mutation rate in the 389 mitochondrial genome, to a large effective population size, or recent population expansion. While data to 390 estimate a mutation rate specific to $P$. caudata are currently unavailable, large population size and/or recent 391 population expansion may explain the large number of singletons in cox-1. P. caudata likely has large 392 population sizes, as the density of individuals has been estimated at $\sim 65,000$ individuals $/ \mathrm{m}^{-2}$ (Faroni-Perez, 393 2014). Given that the generation time of $P$. caudata is of one year, a large fraction of individuals potentially 394 contribute to the gene pool each year. In addition, Bayesian skyline plots (Figure 4) and significant negative 395 values for Fu's Fs and Tajima's D are indicative of recent population expansion (dating to $c$. $200 \mathrm{ka}$ ). Each 
396 of these factors may explain, alone or in combination, the high polymorphism observed in the mitochondrial 397 locus.

398 Within the Brazilian Province, no significant population structure was observed for P. caudata.

399 Long-distance connectivity along the coast of Brazil is known for other invertebrates, including broadcasting 400 corals (Nunes et al., 2009, 2011) and fiddler crabs (Laurenzano et al., 2013; Wieman et al., 2014).

401 Nevertheless, the lack of genetic differentiation along $>5000 \mathrm{~km}$ from Fortaleza to Ilha do Mel was 402 unexpected. For example, the "coastal/island" species of the fireworm Eurythoe complanata shows 403 significant population structure along the coast of Brazil (Barroso et al., 2010), despite having a similar 404 larval duration to $P$. caudata. The data presented here suggest that $P$. caudata can overcome various barriers 405 to dispersal that are known for other marine organisms within the Brazilian Province, such as the split 406 between the north-flowing North Brazil Current and south-flowing Brazil Current (Santos et al., 2006), the 407 São Francisco Barrier (Floeter et al., 2001; Picciani et al., 2016; Souza et al., 2017) and the upwelling at 408 Cabo Frio (for the coral M. hispida, L. Peluso, UFRJ, pers. comm.).

South of the Point of Natal, the Brazil Current is a powerful western-boundary current that may

410 facilitate larval transport and gene flow (Figure 1a). Currently only a few studies have addressed genetic 411 connectivity in annelids in the Brazilian Province (Barroso et al., 2010; Ahrens et al., 2013). Future work on

412 other annelid species may help identify traits that favour or hinder connectivity in this biogeographical 413 region. Finally, for a better understanding of $P$. caudata population connectivity, the use of higher resolution 414 markers such as such as microsatellites or SNPs derived from RAD-Seq could be used to examine finer415 scale population structure and dispersal dynamics.

\section{Conclusions}

Molecular data from two loci (cox-1 and ITS-1) confirms the occurrence of a single species, 420 species range, possibly due to high gamete density upon spawning, long pelagic larval stage, and larvae that 421 are tolerant to a wide range of temperatures, and possibly salinity. The Amazon plume, other major rivers 422 along the coast of Brazil or the upwelling in Cabo Frio are not effective barriers for dispersal for this species, 
as connectivity is maintained along the entire coast of Brazil and between Brazil and the eastern Caribbean.

424 Population structure is observed only in comparisons with the Florida population, possibly due to ecological 425 speciation in the transition zone between tropical and subtropical environments. Additional sampling within 426 the Caribbean is needed to identify whether other barriers to dispersal occur within this biogeographical 427 region.

\section{Acknowledgements}

430 The authors would like to thank C. Bouchon (Université des Antilles et de la Guyane, Guadeloupe, France)

431 for providing specimens, A.C. Panizza (CNPq and Federal University of Ceará, Fortaleza, Brazil) for 432 assistance in the field in Brazil, C.A. Drake (Utah State University, USA) for providing sequence data 433 information for Caribbean populations. This project was supported by the Muséum National d'Histoire 434 Naturelle of Paris (BQR HYDROGENE 2006-2008 and ATM "Formes Possibles, Formes Réalisées" 20132014) to JF. FLDN was supported by the "Laboratoire d'Excellence" LabexMER (ANR-10-LABX-19) and co-funded by a grant from the French government under the program "Investissements d'Avenir", and by a grant from the Regional Council of Brittany. LFP was supported by the São Paulo Research Foundation (FAPESP 07/56340-3) and the National Council for Scientific and Technological Development, Brazil (CNPq - SWE 201233/2015-0).

\section{References}

Ahrens J.B., Borda E., Barroso R., Paiva P.C., Campbell A.M., Wolf A., Nugues M.M., Rouse G.W., \& Schulze A. (2013) The curious case of Hermodice carunculata (Annelida: Amphinomidae): evidence for genetic homogeneity throughout the Atlantic Ocean and adjacent basins. Molecular Ecology, 22, $2280-2291$.

Andras J.P., Kirk N.L., \& Harvell C.D. (2011) Range-wide population genetic structure of Symbiodinium associated with the Caribbean Sea fan coral, Gorgonia ventalina. Molecular Ecology, 20, 2525-2542.

Ataide M.B., Venekey V., Rosa Filho J.S., \& Santos P.J.P. (2014) Sandy reefs of Sabellaria wilsoni (Polychaeta: Sabellariidae) as ecosystem engineers for meiofauna in the Amazon coastal region, Brazil. Marine Biodiversity, 44, 403-413.

Avise J.C. (1992) Molecular population structure and the biogeographic history of a regional fauna - a case history with lessons for conservation biology. Oikos, 63, 62-76.

Barroso R., Klautau M., Solé-Cava A.M., \& Paiva P.C. (2010) Eurythoe complanata (Polychaeta: Amphinomidae), the "cosmopolitan" fireworm, consists of at least three cryptic species. Marine Biology, 157, 69-80. 
Briggs J.C. (1995) Global Biogeography. Elsevier, Amsterdam.

Briggs J.C. \& Bowen B.W. (2012) A realignment of marine biogeographic provinces with particular reference to fish distributions. Journal of Biogeography, 39, 12-30.

Capa M., Hutchings P., \& Peart R. (2012) Systematic revision of Sabellariidae (Polychaeta) and their relationships with other polychaetes using morphological and DNA sequence data. Zoological Journal of the Linnean Society, 164, 245-284.

Carlin J.L., Robertson D.R., \& Bowen B.W. (2003) Ancient divergences and recent connections in two tropical Atlantic reef fishes Epinephelus adscensionis and Rypticus saponaceous (Percoidei: Serranidae). Marine Biology, 143, 1057-1069.

Clement M., Posada D., \& Crandall K. a. (2000) TCS: A computer program to estimate gene genealogies. Molecular Ecology, 9, 1657-1659.

Coleman A.W. \& Vacquier V.D. (2002) Exploring the phylogenetic utility of ITS sequences for animals: a test case for abalone (Haliotis). Journal of Molecular Evolution, 54, 246-257.

Corander J., Marttinen P., Tang J., Sirén J., \& Tang J. (2008) Enhanced Bayesian modelling in BAPS software for learning genetic structures of populations. BMC Bioinformatics, 9, 359.

Denis F., Ravallec R., Pavillon J.-F., \& Van Wormhoudt A. (2009) Genetic differentiation of Atlantic populations of the intertidal copepod Tigriopus brevicornis. Scientia Marina, 73, 579-587.

Drake C.A., McCarthy D.A., \& Von Dohlen C.D. (2007) Molecular relationships and species divergence among Phragmatopoma spp. (Polychaeta: Sabellaridae) in the Americas. Marine Biology, 150, 345358.

Drummond A.J., Rambaut A., Shapiro B., \& Pybus O.G. (2005) Bayesian coalescent inference of past population dynamics from molecular sequences. Molecular Biology and Evolution, 22, 1185-1192.

Dubois S., Retiere C., \& Olivier F. (2002) Biodiversity associated with Sabellaria alveolata (Polychaeta: Sabellariidae) reefs: effects of human disturbances. Journal of Marine Biology Association of the United Kingdom, 82, 817-826.

Eckelbarger K.J. (1976) Larval development and population aspects of the reef-building polychaete Phragmatopoma lapidosa from the east coast of Florida. Bulletin of Marine Science, 26, 117-132.

Excoffier L., Laval G., \& Schneider S. (2005) Arlequin (version 3.0): An integrated software package for population genetics data analysis. Evolutionary Bioinformatics Online, 1, 47-50.

Faroni-Perez L. (2014) Seasonal variation in recruitment of Phragmatopoma caudata (Polychaeta, Sabellariidae) in the southeast coast of Brazil: validation of a methodology for categorizing age classes. Iheringia, 104, 5-13.

Faroni-Perez L., Helm C., Burghardt I., Hutchings P., \& Capa M. (2016) Anterior sensory organs in Sabellariidae (Annelida). Invertebrate Biology, 135, 423-447.

Faroni-Perez L. \& Zara F.J. (2014) Oogenesis in Phragmatopoma (Polychaeta: Sabellariidae): evidence for morphological distinction among geographically remote populations. Memoirs of Museum Victoria, 71, $53-65$.

Floeter S.R., Guimaraes R.Z.P., Rocha L.A., Ferreira C.E.L., Rangel C.A., \& Gasparini J.L. (2001) Geographic variation in reef-fish assemblages along the Brazilian coast. Global Ecology and Biogeography, 10, 423-431.

Floeter S.R., Rocha L.A., Robertson D.R., Joyeux J.C., Smith-Vaniz W.F., Wirtz P., Edwards A.J., Barreiros J.P., Ferreira C.E.L., Gasparini J.L., Brito A., Falcón J.M., Bowen B.W., \& Bernardi G. (2008) Atlantic reef fish biogeography and evolution. Journal of Biogeography, 35, 22-47.

Fournier J., Etienne S., \& Le Cam J.-B. (2010) Inter- and intraspecific variability in the chemical composition of the mineral phase of cements from several tube-building polychaetes. Geobios, $\mathbf{4 3}$, 191-200.

Goldberg W.M. (2013) The Biology of reefs and reef organisms. University of Chicago Press, Chicago.

Hartman O. (1944) Polychaetous Annelids. Part VI. Paraonidae, Magelonidae, Longosomidae, Ctenodrilidae, and Sabellariidae. Allan Hancock Pacific Expeditions, 10, 311-389, NaN-342.

Heled J. \& Drummond A.J. (2010) Bayesian inference of species trees from multilocus data. Molecular Biology and Evolution, 27, 570-580.

Heller R., Chikhi L., \& Siegismund H.R. (2013) The confounding effect of population structure on Bayesian skyline plot inferences of demographic history. PLOS ONE, 8, e62992. 
Kirtley D.W. (1994) A review and taxonomic revision of the family Sabellariidae Johnston 1865 (Annelida; Polychaeta). Sabecon Press, Science Series, Vero Beach.

Laurenzano C., Mantelatto F.L.M., \& Schubart C.D. (2013) South American homogeneity versus Caribbean heterogeneity: population genetic structure of the western Atlantic fiddler crab Uca rapax (Brachyura, Ocypodidae). Journal of Experimental Marine Biology and Ecology, 449, 22-27.

Lazoski C., Solé-Cava A., Boury-Esnault N., M K., \& Russo C.A.M. (2001) Cryptic speciation in a high gene flow scenario in the oviparous marine sponge Chondrosia reniformis. Marine Biology, 139, 421429.

Lessios H.A. (2008) The great American schism: divergence of marine organisms after the rise of the Central American isthmus. Annual Review of Ecology, Evolution, and Systematics, 39, 63-91.

Lessios H.A., Kane J., \& Robertson D.R. (2003) Phylogeography of the pantropical sea urchin Tripneustes: contrasting patterns of population structure between oceans. Evolution, 57, 2026-2036.

Librado P. \& Rozas J. (2009) DnaSP v5: A software for comprehensive analysis of DNA polymorphism data. Bioinformatics, 25, 1451-1452.

Liñero-Arana I. (2013) New records of Sabellariidae (Annelida: Polychaeta) from the Caribbean sea. Interciencia, 38, 382-386.

Main M.B. \& Nelson W.G. (1988) Sedimentary characteristics of sabellariid worm reefs (Phragmatopoma lapidosa Kinberg). Estuarine, Coastal and Shelf Science, 26, 105-109.

Mauro N.A. (1975) The premetamorphic developmental rate of Phragmatopoma lapidosa Kinberg, 1867, compared with that in temperate sabellariids (Polychaeta: Sabellariidae). Bulletin of Marine Science, 25, 387-392.

Mauro N.A. (1977) Variations in osmoregulatory capacity in two species of intertidal sabellariids (Annelida: Polychaeta) from tropical and mediterranean habitats. Comparative Biochemistry and Physiology Part A: Physiology, 56A, 375-377.

McCarthy D. a., Young C.M., \& Emson R.H. (2003) Influence of wave-induced disturbance on seasonal spawning patterns in the sabellariid polychaete Phragmatopoma lapidosa. Marine Ecology Progress Series, 256, 123-133.

Mendonça F.F., Oliveira C., Gadig O.B.F., \& Foresti F. (2013) Diversity and genetic population structure of the Brazilian sharpnose shark Rhizoprionodon lalandii. Aquatic Conservation: Marine and Freshwater Ecosystems, 23, 850-857.

Molleri G.S.F., Novo E.M.L. de M., \& Kampel M. (2010) Space-time variability of the Amazon River plume based on satellite ocean color. Continental Shelf Research, 30, 342-352.

Nóbrega R., Solé-Cava A.M., \& Russo C. a. M. (2004) High genetic homogeneity of an intertidal marine invertebrate along $8000 \mathrm{~km}$ of the Atlantic coast of the Americas. Journal of Experimental Marine Biology and Ecology, 303, 173-181.

Noernberg M.A., Fournier J., Dubois S., \& Populus J. (2010) Using airborne laser altimetry to estimate Sabellaria alveolata (Polychaeta: Sabellariidae) reefs volume in tidal flat environments. Estuarine, Coastal and Shelf Science, 90, 93-102.

Nunes F., Norris R.D., \& Knowlton N. (2009) Implications of isolation and low genetic diversity in peripheral populations of an amphi-Atlantic coral. Molecular Ecology, 18, 4283-97.

Nunes F.L.D., Norris R.D., \& Knowlton N. (2011) Long distance dispersal and connectivity in amphiAtlantic corals at regional and basin scales. PLOS ONE, 6, e22298.

Pagliosa P.R., Doria J.G., Misturini D., Otegui M.B.P., Oortman M.S., Weis W.A., Faroni-Perez L., Alves A.P., Camargo M.G., Amaral A.C.Z., Marques A.C., \& Lana P.C. (2014) NONATObase: a database for Polychaeta (Annelida) from the Southwestern Atlantic Ocean. Database, 2014, bau002.

Palumbi S.R. (1994) Genetic divergence, reproductive isolation, and marine speciation. Annual Review of Ecology and Systematics, 25, 547-572.

Pawlik J.R. (1988) Larval settlement and metamorphosis or Sabellariid polychaetes, with special reference to Phragmatopoma lapidosa, a reef-building species, and Sabellaria floridensis, a non-gregarious species. Bulletin of Marine Science, 43, 41-60.

Picciani N., Seiblitz I.G.L., Paiva P.C., Castro C.B., \& Zilberberg C. (2016) Geographic patterns of Symbiodinium diversity associated with the coral Mussismilia hispida (Cnidaria, Scleractinia) correlate with major reef regions in the Southwestern Atlantic Ocean. Marine Biology, 163, 236. 
Rocha L.A., Robertson D.R., Roman J., \& Bowen B.W. (2005) Ecological speciation in tropical reef fishes. Proceedings of the Royal Society B: Biological Sciences, 272, 573-579.

Santos M.V.Q.B., Aquino-Souza R., \& Gomes-Filho J.G.F. (2012) Ocorrência, grau de ocupação do substrato e tamanhos das colônias de Phragmatopoma caudata na região entremarés da Praia da Pedra do Sal, Parnaíba-PI.

Santos S., Hrbek T., Farias I.P., Schneider H., \& Sampaio I. (2006) Population genetic structuring of the king weakfish, Macrodon ancylodon (Sciaenidae), in Atlantic coastal waters of South America: deep genetic divergence without morphological change. Molecular Ecology, 15, 4361-4373.

Souza J.N., Nunes F.L.D., Zilberberg C., Sanchez J.A., Migotto A.E., Hoeksema B.W., Serrano X.M., Baker A.C., \& Lindner A. (2017) Contrasting patterns of connectivity among endemic and widespread fire coral species (Millepora spp.) in the tropical Southwestern Atlantic. Coral Reefs, in press.

Tamura K., Stecher G., Peterson D., Filipski A., \& Kumar S. (2013) MEGA6: Molecular evolutionary genetics analysis version 6.0. Molecular Biology and Evolution, 30, 2725-2729.

Terossi M. \& Mantelatto F.L.A. (2012) Morphological and genetic variability in Hippolyte obliquimanus Dana, 1852 (Decapoda, Caridae, Hippolytidae) from Brazil and the Caribbean Sea. Crustaceana, 85, $685-712$.

Wieman A.C., Berendzen P.B., Hampton K.R., Jang J., Hopkins M.J., Jurgenson J., McNamara J.C., \& Thurman C.L. (2014) A panmictic fiddler crab from the coast of Brazil? Impact of divergent ocean currents and larval dispersal potential on genetic and morphological variation in Uca maracoani. Marine Biology, 161, 173-185.

Zigler K.S. \& Lessios H.A. (2004) Speciation on the coasts of the new world: phylogeography and the evolution of binding in the sea urchin genus Lytechinus. Evolution, 58, 1225-1241.

\section{Supporting Information}

Additional Supporting Information may be found in the online version of this article:

Appendix S1. Sampling coordinates and location details.

Appendix S2. Genetic diversity indices for (a) $\operatorname{cox}-1$ and (b) ITS- 1

Appendix S3. BAPS assignments for (a) cox-1 and (b) ITS-1.

\section{Biosketches}

Flavia Nunes is an evolutionary biologist interested in population connectivity, speciation and adaptation in

marine invertebrates

\section{Author contributions:}

AVW and JF conceived the project; JF and LFP collected the samples; AVW and FLDN did the molecular analyses, AVW, FLDN and JF analysed the data. FLDN, AVW, LFP and JF contributed to writing the manuscript. 
601 Editor: Michelle Gaither

602

603 Data accessibility

604 DNA sequences produced during this study have been deposited in Genbank (see Methods and Materials for 605 details). Raw data can be requested by contacting the corresponding author (Flavia.nunes@ifremer.fr) 606 


\section{FIGURES}

608 Figure 1. (a) Map of the sampling site locations of $P$. caudata, showing the direction of major ocean

609 currents in January for the western Atlantic Ocean and Caribbean Sea. Haplotype frequencies are shown for

610 each population for (b) of cox-1 and (c) ITS-1. Population codes: Florida (FLO), Puerto Rico (PRI), Virgin

611 Islands (VIL), Guadeloupe (GUA), Fortaleza (FOR), Tamandaré (TAM), Peracanga (PER), Ubatuba (UBA),

612 Porchat (POR), Itanhaém (ITA) and Ilha do Mel (MEL).

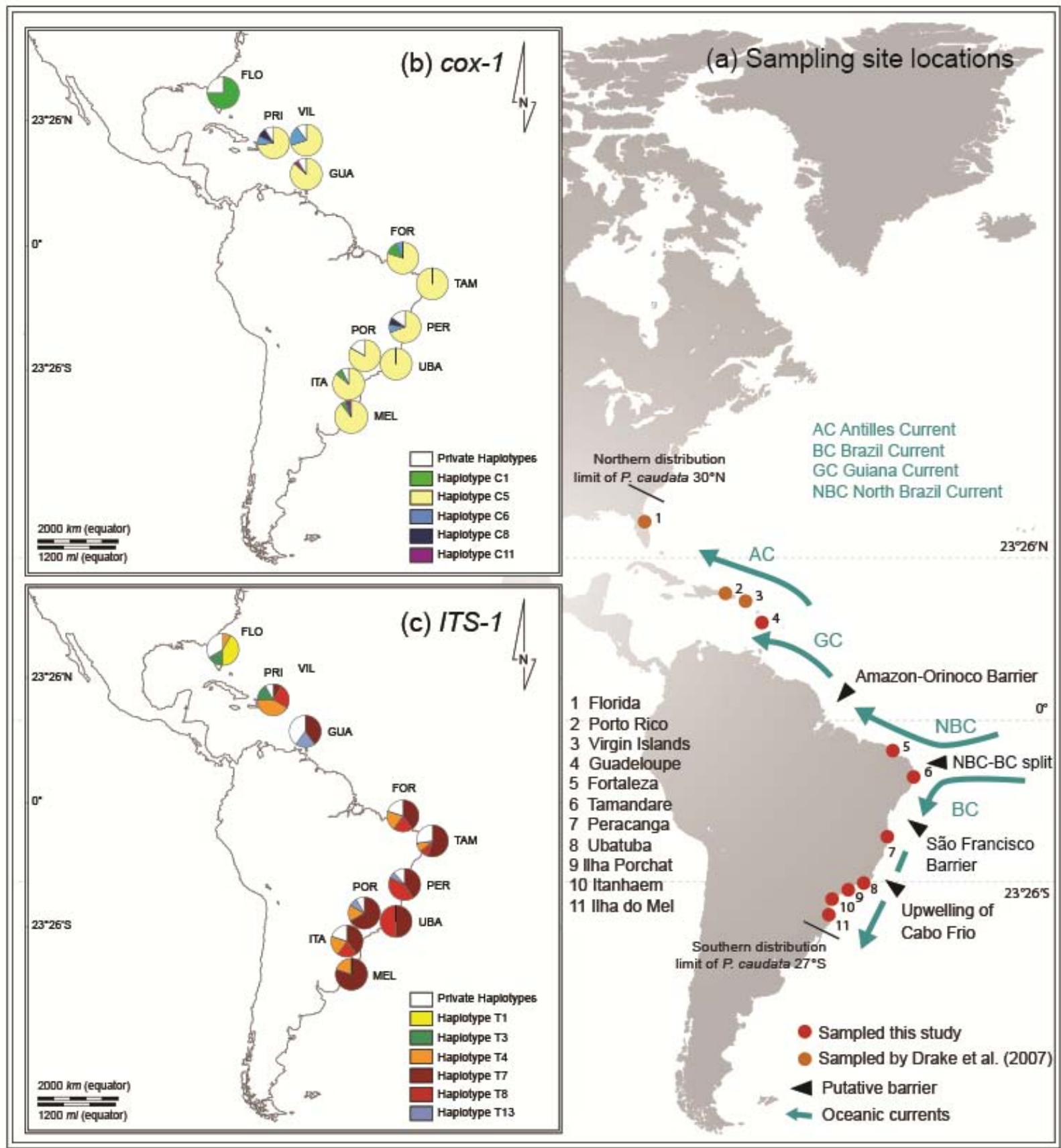


614 Figure 2. Phylogenetic reconstruction of relationships among species of Phragmatopoma. (a) Species tree

615 based on combined data from cox-1 and ITS-1; (b) based on sequences of ITS- 1 and (c) based on sequences

616 of cox-1. Posterior probabilities are shown for nodes with support $>0.90$. Species are colour-coded as

617 follows: red: $P$. caudata, orange: $P$. caudata from the Florida population, blue: $P$. californica; green: $P$.

618 virgini; cyan: P. moerchi; black: I. cretus. (F) denotes individuals of P. caudata from the Florida population.
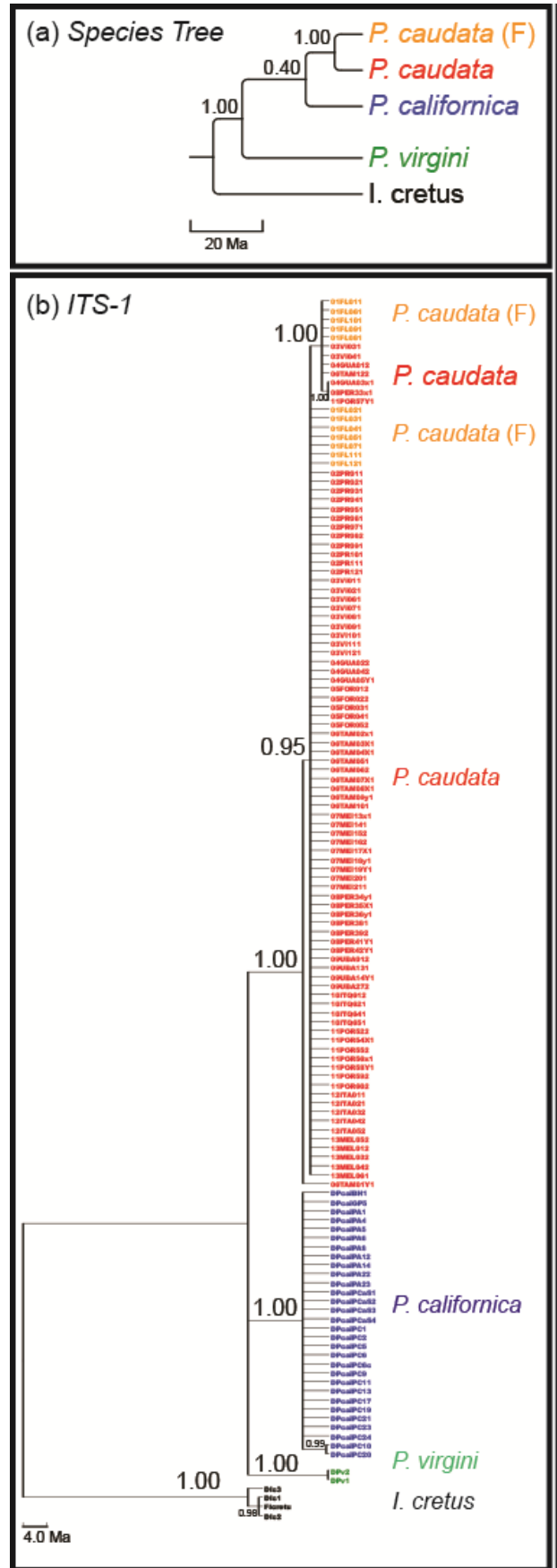

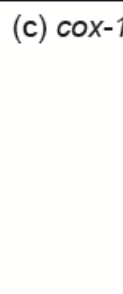

(c) $\cos -1$

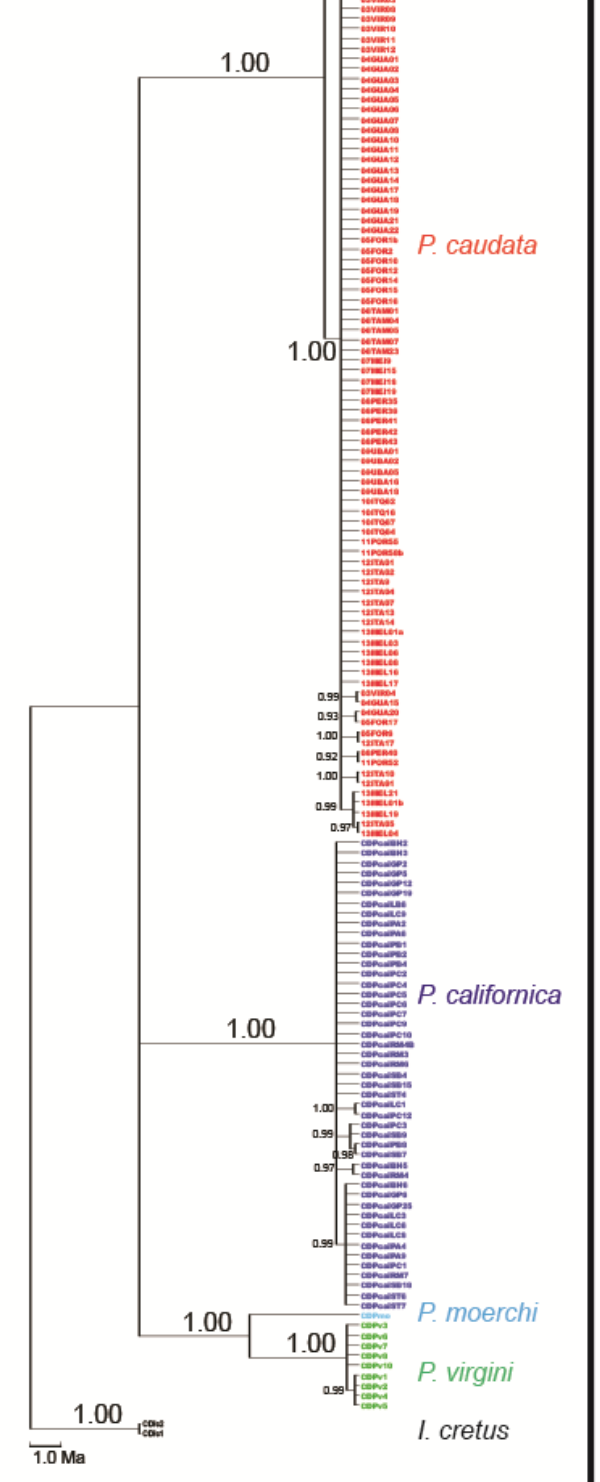


620 Figure 3. Haplotype networks based on sequences of $P$. caudata for (a) cox-1 and (b) ITS-1. Each circle

621 represents a haplotype and its size is proportional to the frequency of the haplotype across all populations.

622 Empty circles represent mutational steps between sampled haplotypes. Haplotypes are colour-coded by

623 geographic region: red = Florida (FLO); yellow = eastern Caribbean (PRI, VIL, GUA); green = Brazil $($ FOR,

624 TAM, PER, UBA, POR, ITA, MEL). See Figure 1 for population code names.

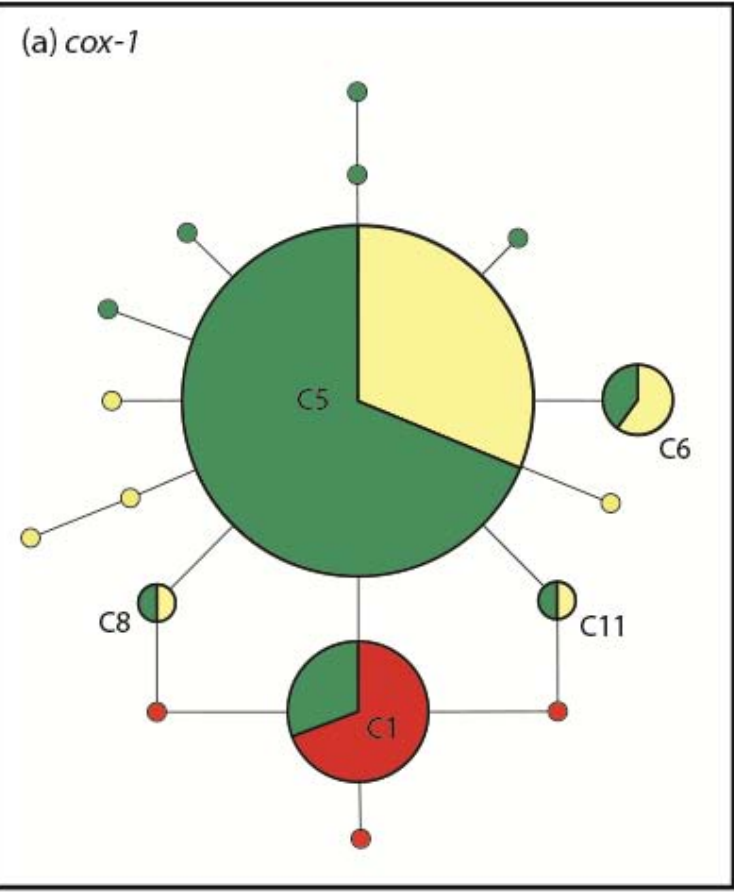

Florida

Eastern Caribbean

Brazil

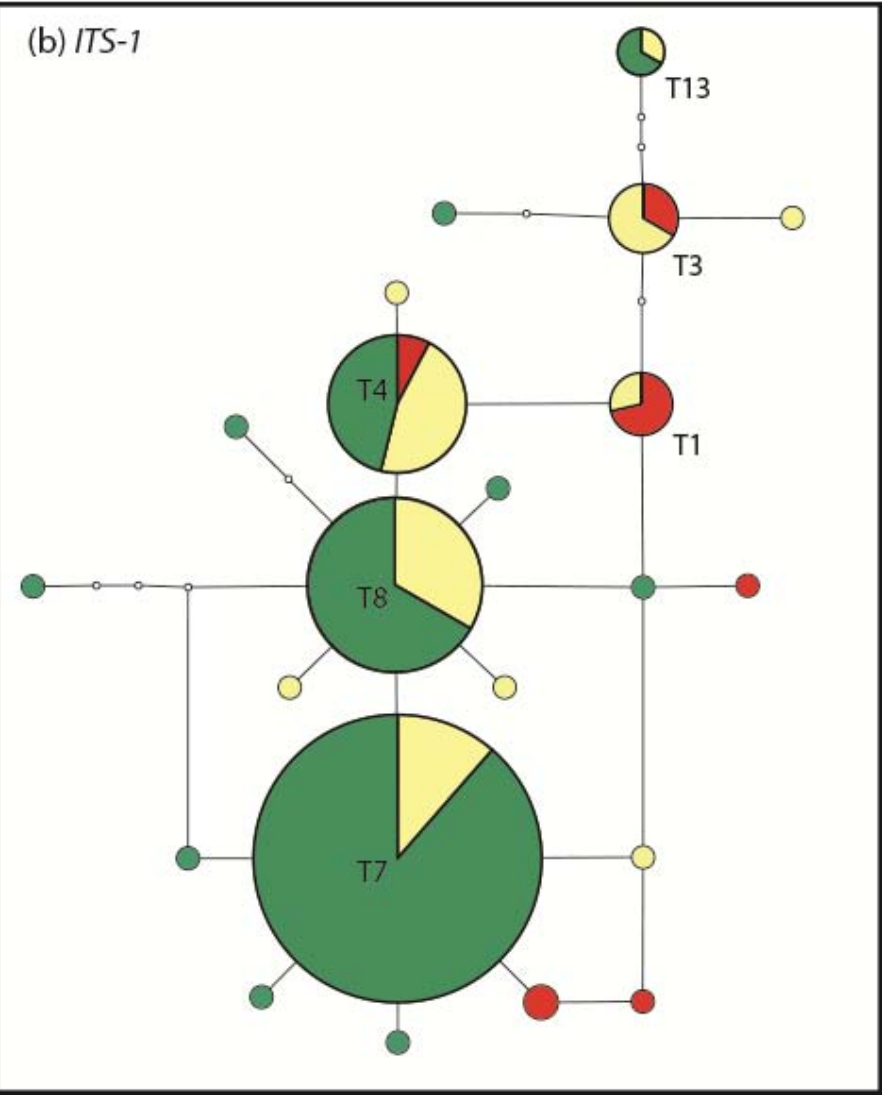


627 Figure 4. Bayesian skyline plots showing changes in effective population size of $P$. caudata over time based 628 on sequences from: (a) cox-1; (b) cox-1 excluding individuals from Florida; (c) ITS-1 and (d) ITS-1

629 excluding individuals from Florida.

630
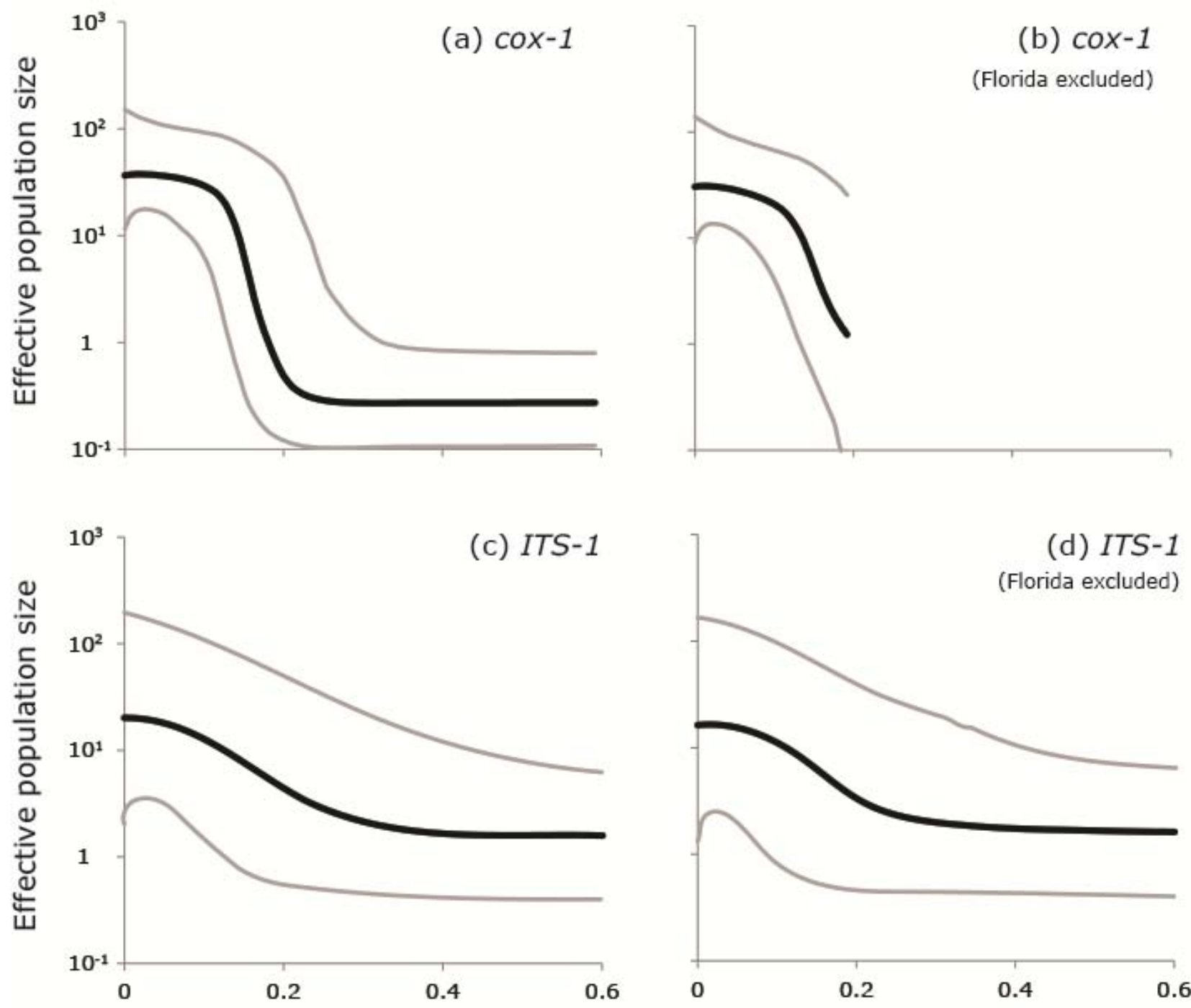
TABLES

634 Table 1. Estimates of evolutionary divergences between species pairs of Phragmatopoma, and outgroup, $I$. 635 cretus. The number of base substitutions per site from averaging over all sequence pairs between species is 636 shown below the diagonal, and standard error estimates are shown above the diagonal for (a) cox- 1 and (c) 637 ITS-1. Divergence time estimates using locus-specific substitution rates are shown for each species pairs for 638 (b) cox-1 and (d) ITS-1. (F) denotes the Florida population of P. caudata.

(a) Genetic distances between species pairs based on cox-1

$\begin{array}{llcccccc} & \mathbf{1} & \mathbf{2} & \mathbf{3} & \mathbf{4} & \mathbf{5} & \mathbf{6} \\ \mathbf{1} & \text { I. cretus } & & 0.019 & 0.022 & 0.022 & 0.024 & 0.024 \\ \mathbf{2} & \boldsymbol{P} \text {. californica } & 0.180 & & 0.021 & 0.022 & 0.021 & 0.020 \\ \mathbf{3} & \boldsymbol{P} \text {. } \text { moerchi } & 0.192 & 0.186 & & 0.016 & 0.021 & 0.020 \\ \mathbf{4} & \boldsymbol{P} \text {. virgini } & 0.203 & 0.202 & 0.121 & & 0.021 & 0.021 \\ \mathbf{5} & \boldsymbol{P} \text {. caudata }(\mathbf{F}) & 0.216 & 0.193 & 0.194 & 0.194 & & 0.007 \\ \mathbf{6} & \boldsymbol{P} \text {. caudata } & 0.218 & 0.181 & 0.183 & 0.200 & 0.032 & \end{array}$

(b) Divergence time estimates between species pairs based on a $2.1 \%$ substitution rate for cox- 1

\begin{tabular}{|c|c|c|c|c|c|c|c|}
\hline & & 1 & 2 & 3 & 4 & 5 & 6 \\
\hline 1 & I. cretus & & 0.9 & 1.0 & 1.1 & 1.1 & 1.1 \\
\hline 2 & P. californica & 8.6 & & 1.0 & 1.0 & 1.0 & 1.0 \\
\hline 3 & P. moerchi & 9.2 & 8.8 & & 0.8 & 1.0 & 1.0 \\
\hline 4 & $P$. virgini & 9.7 & 9.6 & 5.8 & & 1.0 & 1.0 \\
\hline 5 & P. caudata $(\mathbf{F})$ & 10.3 & 9.2 & 9.2 & 9.3 & & 0.3 \\
\hline 6 & P. caudata & 10.4 & 8.6 & 8.7 & 9.5 & 1.5 & \\
\hline
\end{tabular}

(c) Genetic distances between species pairs based on ITS-1

$\begin{array}{llccccc} & & \mathbf{1} & \mathbf{2} & \mathbf{3} & \mathbf{4} & \mathbf{5} \\ \mathbf{1} & \text { I. } \text { cretus } & & 0.036 & 0.036 & 0.036 & 0.036 \\ \mathbf{2} & \boldsymbol{P} \text {. } \text { californica } & 0.353 & & 0.013 & 0.014 & 0.013 \\ \mathbf{3} & \boldsymbol{P} \text {. } \text { virgini } & 0.339 & 0.075 & & 0.015 & 0.015 \\ \mathbf{4} & \boldsymbol{P} \text {. caudata }(\mathbf{F}) & 0.340 & 0.073 & 0.085 & & 0.003 \\ \mathbf{5} & \boldsymbol{P} \text {. caudata } & 0.339 & 0.070 & 0.083 & 0.008 & \end{array}$

(d) Divergence time estimates between species pairs based on a $0.25 \%$ substitution rate for ITS- 1

\begin{tabular}{|c|c|c|c|c|c|c|}
\hline & & 1 & 2 & 3 & 4 & 5 \\
\hline 1 & I. cretus & & 14.6 & 14.2 & 14.4 & 14.3 \\
\hline 2 & P. californica & 141.2 & & 5.3 & 5.4 & 5.4 \\
\hline 3 & P. virgini & 135.5 & 29.9 & & 6.0 & 5.9 \\
\hline 4 & P. caudata $(\mathrm{F})$ & 136.0 & 29.2 & 33.9 & & 1.2 \\
\hline 5 & P. caudata & 135.5 & 28.2 & 33.1 & 3.2 & \\
\hline
\end{tabular}


640 Table 2. Analysis of molecular variance (AMOVA) for (a) cox-1 and (b) ITS-1; based on two groups of

641 populations of P. caudata: Group 1: Florida (FLO); Group 2: Puerto Rico (PRI), Virgin Islands (VIL),

642 Guadeloupe (GUA), Fortaleza (FOR), Tamandaré (TAM), Peracanga (PER), Ubatuba (UBA), Porchat

643 (POR), Itanhaém (ITA) and Ilha do Mel (MEL). $\mathrm{F}_{\mathrm{CT}}$ : variation among groups; $\mathrm{F}_{\mathrm{SC}}$ : variation among

644 populations within groups; $\mathrm{F}_{\mathrm{ST}}$ : variation within populations. Significant values $(P<0.05)$ are highlighted in 645 bold.

(a) Analysis of Molecular Variance for cox-1

\begin{tabular}{llccc} 
Source of variation & df & Sum of Squares & $\begin{array}{c}\text { Variance } \\
\text { Components }\end{array}$ & $\begin{array}{c}\% \text { of } \\
\text { Variation }\end{array}$ \\
\hline
\end{tabular}

$\begin{array}{lccccc}\text { Among groups } & 1 & 10.556 & 0.47092 & \mathrm{Va} & 72.07 \\ \begin{array}{l}\text { Among populations } \\ \text { within groups }\end{array} & 9 & 1.649 & 0.00006 & \mathrm{Vb} & 0.01 \\ \text { Within populations } & 135 & 24.623 & 0.18239 & \mathrm{Vc} & 27.92\end{array}$

$\begin{array}{llll}\text { Total } & 145 & 36.829 & 0.65338\end{array}$

$\begin{array}{lll}\text { Fixation Indices } & & \text { p-value } \\ \mathrm{F}_{\mathrm{SC}}(\mathrm{Vb}) & 0.00035 & 0.37146 \\ \mathrm{~F}_{\mathrm{ST}}(\mathrm{Vc}) & \mathbf{0 . 7 2 0 8 5} & 0.00000 \\ \mathrm{~F}_{\mathrm{CT}}(\mathrm{Va}) & 0.72075 & 0.08798\end{array}$

(b) Analysis of Molecular Variance for ITS- 1

\begin{tabular}{|c|c|c|c|c|c|}
\hline Source of variation & df & Sum of Squares & $\begin{array}{c}\text { Variance } \\
\text { Components }\end{array}$ & & $\begin{array}{c}\% \text { of } \\
\text { Variation } \\
\end{array}$ \\
\hline Among groups & 1 & 12.894 & 0.24476 & $\mathrm{Va}$ & 19.57 \\
\hline $\begin{array}{l}\text { Among populations } \\
\text { within groups }\end{array}$ & 9 & 10.559 & 0.02209 & $\mathrm{Vb}$ & 1.77 \\
\hline Within populations & 88 & 86.567 & 0.98372 & $\mathrm{Vc}$ & 78.66 \\
\hline Total & 98 & 110.02 & 1.25057 & & \\
\hline Fixation Indices & & p-value & & & \\
\hline $\mathrm{F}_{\mathrm{SC}}(\mathrm{Vb})$ & 0.02196 & 0.13881 & & & \\
\hline $\mathrm{F}_{\mathrm{ST}}(\mathrm{Vc})$ & 0.21338 & 0.00000 & & & \\
\hline $\mathrm{F}_{\mathrm{CT}}(\mathrm{Va})$ & 0.19572 & 0.00098 & & & \\
\hline
\end{tabular}

Population Structure:

Population 1

FLO 
647 Table 3. Pairwise $\varphi_{\mathrm{ST}}$ among populations of $P$. caudata. Values in the upper triangle were calculated based on ITS-1, while values in the lower triangle were

648 calculated based on cox-1. Statistically significant values $(P<0.05)$ are highlighted in bold. Underlined values indicate significance after Bonferroni correction

$649 \quad(P<0.00091)$

650

\begin{tabular}{|c|c|c|c|c|c|c|c|c|c|c|c|c|c|}
\hline & & & $\begin{array}{c}\text { FLO } \\
1\end{array}$ & $\begin{array}{c}\text { PRI } \\
2\end{array}$ & $\begin{array}{c}\text { VIL } \\
3\end{array}$ & $\begin{array}{c}\text { GUA } \\
4\end{array}$ & $\begin{array}{c}\text { FOR } \\
5\end{array}$ & $\begin{array}{c}\text { TAM } \\
6\end{array}$ & $\begin{array}{c}\text { PER } \\
7\end{array}$ & $\begin{array}{c}\text { UBA } \\
8\end{array}$ & $\begin{array}{c}\text { POR } \\
9\end{array}$ & $\begin{array}{c}\text { ITA } \\
10\end{array}$ & MEL \\
\hline Florida & FLO & 1 & & 0.234 & 0.060 & 0.001 & 0.284 & 0.207 & $\underline{0.339}$ & 0.305 & 0.305 & 0.284 & 0.329 \\
\hline Puerto Rico & PRI & 2 & $\underline{0.615}$ & & -0.005 & 0.229 & 0.204 & 0.132 & $\underline{0.195}$ & 0.260 & 0.249 & 0.204 & 0.337 \\
\hline Virgin Islands & VIR & 3 & $\underline{0.661}$ & -0.024 & & 0.051 & 0.150 & 0.090 & 0.173 & 0.164 & 0.205 & 0.150 & 0.241 \\
\hline Guadeloupe & GUA & 4 & $\underline{0.746}$ & 0.009 & 0.082 & & 0.071 & 0.026 & 0.163 & 0.085 & 0.069 & 0.071 & 0.097 \\
\hline Fortaleza, BR & FOR & 5 & $\underline{0.632}$ & 0.003 & 0.018 & 0.034 & & -0.091 & -0.049 & -0.166 & -0.086 & -0.167 & -0.146 \\
\hline Tamandaré, BR & TAM & 6 & $\underline{0.753}$ & -0.046 & 0.028 & -0.070 & -0.022 & & -0.012 & -0.123 & -0.024 & -0.110 & -0.073 \\
\hline Peracanga, BR & PER & 7 & $\underline{0.606}$ & -0.039 & -0.017 & 0.019 & 0.002 & -0.055 & & -0.142 & 0.030 & -0.049 & 0.013 \\
\hline Ubatuba, BR & UBA & 8 & $\underline{0.784}$ & -0.009 & 0.074 & -0.043 & 0.012 & 0.000 & -0.022 & & -0.065 & -0.166 & -0.053 \\
\hline Porchat, BR & POR & 9 & $\underline{0.706}$ & 0.003 & 0.053 & 0.005 & 0.025 & -0.051 & -0.026 & -0.016 & & -0.086 & -0.125 \\
\hline Itanhaém, BR & ITA & 10 & $\underline{0.691}$ & 0.009 & 0.062 & 0.001 & -0.030 & -0.058 & 0.003 & -0.026 & 0.001 & & -0.146 \\
\hline Ilha do Mel, BR & MEL & 11 & $\underline{0.735}$ & 0.025 & 0.086 & -0.021 & -0.012 & -0.067 & 0.016 & -0.038 & 0.008 & -0.029 & \\
\hline
\end{tabular}

